\title{
PENGARUH METODE PARTISIPATORI DAN MINAT BELAJAR TERHADAP KEMAMPUAN BERWIRAUSAHA SISWA SMK
}

\author{
Siti Alifah ${ }^{1]}$, Dwi Narsih ${ }^{2]}$, Sigit Widiyarto ${ }^{3]}$ \\ Universitas Indraprasta PGRI Jakarta \\ E-mail: sitialifah@gmail.com \\ unindra103@gmail.com \\ sigit.widiyanto372@gmail.com
}

\begin{abstract}
Abstrak
Bidang kewirausahaan yang dilaksanakan di sekolah perlu mendapat perhatian khusus. Pemerintah dan masyarakat perlu bekerjasama dalam meningkatkan minat dan kemampuan berwirausaha siswa. Pihak sekolah perlu menggunakan metode pembelajaran yang tepat dan sesuai dengan kondisi dan situasi sekolah. Guru yang menggunakan metode pembelajaran diharapkan dapat Meningkatkan kemampuan berwirausaha. Namun penggunaan metode sering diabaikan.Sehingga pembelajaran tidak maksimal. Upaya untuk meningkatkan kemampuan berwirausaha perlu digalakkan, dan memerlukan kerjasama yang baik para stakeholder pendidikan. Bidang kewirausahaan sangat penting bagi perkembangan ekonomi indoensia,karena jumlah wirausahawan di Indonesia masih sedikit dibandingkan negara tetangga. Tujuan penelitian ini untuk mengetahui pengaruh metode Partisipatori dan minat belajar terhadap kemampuan berwirausaha. Metode yang digunakan dalam penelitian yaitu metode kuantitatif. Sampel yang digunakan sebanyak 25 siswa SMK. Data diambil dengan menggunakan angket (pada variabel pembelajaran dan minat belajar), sedangkan kemampuan berwirausaha dengan menggunakan tes praktek uji kemampuan. Uji klasik yang digunakan adalah normalitas dan linierlinitas. Setelah itu data diolah dengan menggunakan regresi berganda. Hasil penelitian menunjukkan bahwa, terdapat pengaruh pembelajaran partisipatori dan minat belajar terhadap kemampuan berwirausaha, terdapat pengaruh pembelajaran partisipatori terhadap kemampuan berwirausaha, dan tidak terdapat pengaruh minat belajar terhadap kemampuan berwirausaha. Agar pembelajaran untuk berwirausaha dapat meningkatkan kemampuan berwirausaha, maka perlu adanya pembeajaran yang inovatif dan sesuai dengan kebutuhan siswa SMK.
\end{abstract}

Kata kunci : Partisipatori, minat belajar, kemampuan wirausaha

\section{THE EFFECT OF PARTICIPATORY METHODS AND LEARNING INTEREST TOWARD THE STUDENTS' ABILITY IN ENTREPRENEURSHIP}

\begin{abstract}
The field of entrepreneurship carried out in schools needs special attention. The government and the community need to cooperate in increasing students' interest and entrepreneurship abilities. The school needs to use the right learning method and in accordance with school conditions and situations. Teachers who use learning methods are expected to be able to improve
\end{abstract}


entrepreneurship skills. But the use of methods is often ignored. So learning is not optimal. Efforts to improve entrepreneurial skills need to be encouraged, and require good collaboration with education stakeholders. Entrepreneurship midwives are very important for Indonesia's economic development, because the number of entrepreneurs in Indonesia is still SMKll compared to neighboring countries. The purpose of this study was to determine the effect of Participatory methods and interest in learning on entrepreneurship skills. The method used in the research is quantitative methods. The sample used was 25 SMK students. Data was taken using a questionnaire (on learning variables and interest in learning), while the ability to entrepreneurship using the ability test practice tests. The classic test used is normality and linearity. After that the data is processed using multiple regression. The results showed that, there was the effect of participatory learning and interest in learning on entrepreneurship skills, there was the effect of participatory learning on entrepreneurship skills, and there was no effect of interest in learning about entrepreneurial skills. So that learning for entrepreneurship can improve entrepreneurship skills, it is necessary to have innovative learning and in accordance with the needs of vocational students.

Keywords: Participatory, interest in learning, entrepreneurship ability

\section{PENDAHULUAN}

Untuk mencapai salah satu cita-cita bangsa yang tertuang dalam Pembukaan Undang-undang Dasar 1945, yaitu mewujudkan masyarakat Indonesia yang adil dan makmur, maka pemerintahan Presiden Joko Widodo telah mencanangkan Sembilan agenda prioritas yang terangkum dalam Nawacita. Beberapa poin Nawacita diantaranya adalah mewujudkan kemandirian ekonomi bangsa serta meningkatkan produktivitas dan daya saing masyarakat. Untuk mewujudkan kemandirian ekonomi, perlu peningkatan wawasan, pemahaman dan aplikasi nyata dari masyarakat untuk berwirausaha. Masyarakat yang memiliki jiwa wirausaha memiliki peran penting dalam pertumbuhan ekonomi, baik secara mikro karena dapat memperkecil angka pengangguran maupun secara makro karena dapat meningkatkan pendapatan perkapita suatu negara, sehingga perlu sosialisasi dan pembinaan terhadap masyarakat akan pentingnya wirausaha (Vernia, D.M, 2018).
Pendidikan Kewirausahaan sebagai salah satu upaya yang dilakukan pemerintah untuk mengembangkan jiwa wira usaha pada siswa SMK dan meningkatkan manusia yang tangguh,dalam bersaing denganpekerja lain,serta dapat menciptakan peluang kerja yang luas dan berkualitas. Siswa sekolah menengah kejuruan sebaiknya mempuyai minat berwirausaha yang tinggi,dapat mengembangkan kemampuan dan potensi yang dimiliki .Sekolah yang sudah mereka jalani,bukan saja tempat untuk mendapatkan pendidikan,tapi menjadi tempat untuk bersosialisasi dan mempelajari nilai-nilai kewirausahaan . Siswa dapat begaul dengan sesame siswa dan guru seta melakukan eksplorasi akan banyak hal.Sekolah hendaknya menjadi tempat potensi seseorang yang akan terlihat, potensi yang akan menjadi bekal untuk masa depan mereka dalam berwirausaha, sehingga mampu mengurangi tingkat pengangguran di Indonesia dan mampu meningkatkan taraf pendapatan masyarakat. 
Dewasa ini, industri kerja sangat membutuhkan tenaga-tenaga para siswal yang mempunyai kompetensi yang baik agar terserap pada era industry 4.0. Industri digital yang akan terus berkembang memerlukan tenaga professional yang mempunyai minat belajar dalam membuka lapangan kerja baru . Hal ini menjadikan sekolah bukan saja tempat menimba ilmu, akan tetapi dapat juga sebagai sekolah yang dapat mempersiapkan siswa menjadi tenagatenaga yang hpara siswal. Oleh karena itu guru disekolah dapat menggunakan metode pembelajaran yang tepat dan efektif. Salah satu metode yang dapat diberikan adalah metode partisipatori. Metode ini mampu meningkatkan kemampuan hasil belajar (Suyana,N dkk, 2019).

Kemampuan guru untuk menggunakan metode pembelajaran, sangat penting,karena keberhasilan pembelajaran yang menarik dan dapat diterima oleh siswa dapat meningkatkan hasil belajar (Ati ,A.P,dkk 2017). Lebih lanjut lagi dapat dikatakan bahwa kegiatan pembelajaran sangat strategis dan menjadi bagian yang paling penting dalam implementasi kurikulum. Jika ingin mengetahui apakah pembelajaran itu sesuai dengan kondisi, dapat diketahui melalui kegiatan pembelajaran. Untuk itu pengajar dalam melaksanakan kegiatan pembelajaran seyogyanya tahu bagaimana membuat kegiatan pembelajaran berjalan dengan baik dan dapat mencapai tujuan pembelajaran yang diharapkan. Ciri utama kegiatan pembelajaran efektif adalah adanya interaksi yang baik dan terukur serta terus mengevaluasi semua hasil capaian belajar. Untuk itulah peneliti ingin mengetahui pengaruh Metode Partisipatori dan minat belajar terhadap hasil mata pelajaran kewirausahaan pada siswa SMK.

\subsection{Minat dan Potensi Belajar}

Pemahaman guru terhadap siswanya sangat diperlukan untuk lebih memahami potensi dan gairah yang dimiliki ole siswa. Mina yang sering dikemukakan oleh para ahi psikologi dapat dikatakan sebagai "passion" .Passion merupakan gairah untuk melakukan sesuatu yang menjadi minat siswa. Namun lebih dari sekedar gairah atau minat,passion merupakan sebuah energi yang timbul agar siswa berani menghadapi setia tantangan yang muncul di dalam sebuah perjalanan untu mencpai tujuan yang benar. Dengan minat yang besar maka, segala rintangan akan dihadapi dengan baik.,sebaliknya tanpa passion pada kewirausahaan,siswa akan mudah menyerah dan kesulitan akan datang silih berganti tnpa adanya penyelesaian yang berarti(Cristin, M 78:2018) . Minat (passioan) tidaklah sama dengan bakat. Kadang 2 hal tersebut dapat tertukar. Bakat merupakan sesuatu yang mampu dilakukan,sedangkan "passion" merupakan sesuatu yang disukaidicintai untuk dilakukan. "passion merupakan titik wal semua pencapaian,tanpa passion seseorang tidak akan dapat mencapai impian.Passion merrupakan bahan bakar yang akan memberikan energi utuk mengerjakan area potensi siswa. Selanjutnya jika siswa dapat mengabungkan potensi dan passion maka siswa dpat melakukan sesuatu yang luar biasa. Pada tahap pengenalan potensi, guru dapat mengarhakan dan membantu untuk menemukan potensi kewirausahaan siswa dengan baik. Melakukan dengan minat saja, tidak menjamin akan selalu berhasil dan tidak pernah gagal.

Pasca pengesahan Undang-undang Nomor 20 Tahun 2003 tentang Sistem Pendidikan Nasional terjadi perubahan besar dalam konteks pengelolaan proses pendidikan di Indonesia. Dalam undang- 
undang tersebut tidak lagi dikenal istilah pengajaran, namun menggunakan istilah pembelajaran. Pada konsep pengajaran akan memunculkan kondisi Teacher Center. Sedangkan pada konsep pembelajaran, guru lebih bersifat fasilitator yang membuat siswa belajar sendiri. Pada konsep ini sangat mungkin relevan terwujudnya Student Center. Maka salah satu komponen penting dalam meningkatkan mutu dan kualitas pendidikan di era globalisasi ini adalah melaksanakan pengelolaan proses pembelajaran (manajemen pembelajaran) dengan berbasis keaktifan siswa didalamnya. Penerapan ini diantaranya adalah dengan Metode Partisipatori, dimana siswa berperan aktif dalam proses pembelajaran.

Pada saat siswa maih dibangku sekolah,guru dapat mendeteksi minat dan bakar siswanya. Hal ini penting,agar siswa dapat memperoleh msukan yang berharga dari guru pada minat dan bakatnya. Guru Bk dapat berkerjasama dengan wali kelas dan guru wali.

Keinginan seseorang untuk melakukan sesuatu didasari oleh suatu motivasi. Hal ini perlu diterapkan oleh guru, artinya guru yag mempunyai keinginan yang kuat dan besar, akan membuahkan hasil yang berkualitas pada anak didiknya. Siswa yang sudah termotivasi, akan memberikan motivasinya kepada siswa yang lain, siswa yang lain akan termotivasi dengan cepat. Siswa akan terdorong dengan cepat, jika guru memberikan contoh dengan motivasi yang kuat, motivasi tersebut dapat meningkatkan prestasi disekolah. Selanjutnya guru yang mempunyai bahan pelajaran yang menarik dan tidak membosankan, akan membuat siswa terpacu utuk belajar. Sebaliknya, jika siswa mendapatkan bahan pelajaran yang membosankan dan tidak menantang bagi mereka,maka siswa lambat laun akan mengalami kesulitan belajar, dan cepat bosan.

Siswa yang mempunyai minat pada pelajaran tertentu, dapat menjadi kekuatan dalam diri siswa untuk belajar dengan giat dan tekun. Sikap menyukai pada pelajaran tertentu,dapat menjadi indicator guru untuk menentukan dibidang mana siswa dpat mengembangkan potensi dirinya kelak setelah selesai SMK. Guru terus mengarahkan, dibidang mana yang dapat dikembagkan,sehingga menjadi bidang yang diminati.

\subsection{Parameter Minat}

Parameter minat yang dapat dirangkum menjadi 4 (perasaan senang, ketertarikan, perhatian dan keterlibatan siswa). Di bawah ini beberapa penjelasan parameter yang dapat menimbulkan minat belajar siswa:

\section{a. Senang}

Siswa dapat menyukai suatu pelajaran, jika dipengaruhi oleh beberpa sebab, diantaranya guru yang professional, bahan ajar yang menari, serta penyajian pelajaran dikelas yang tidak membosankan. Jika siswa menyenangi pelajaran tersebut , maka siswa akan terus menggali potensi yang ada pada pelajaran.

\section{b. Siswa tertarik}

Siswa mempunyai kecenderungan yang besar untuk tertarik,jika ada dorongan yang kuat dari dalam maupun luar diri siswa tersebut.Dengan kegiatan yang diangsang oleg guru,untuk menerima tantangan yang lebih besr,siswa akan terus menerus melakukan kegiatan. 


\section{c. Perhatian Siswa}

Siswa yang mempunyai bakat dan potensi yang besar pada bidang tertentu ,maka siswa memiliki keterkaitan dan perhatian pada bidang yang disukai. Perhatian yang sudah dicurahkan siswa pada kegiatan ,menjadi pemicu kesemangatan untuk melakukan yang terbaik.

\section{d. Pelibatan siswa pada suatu kegiatan}

Siswa yang dilibatkan pada suatu kegiatan, lambat laun akan belajar bagaimana dapat menjalankan suatu kegiatan yang berdapak pada peningkatan minat dan bakat siswa. Seperti pelibatan siswa pada kegiatan ekstrakurikuler memasak dan menanam hidroponik.

\subsection{Minat belajar dan faktor- faktornya}

Minat siswa dapat timbul jika ada yang mempengaruhi. Faktor yang dapat mempengaruhi dapat bersifat dari dalam dan luar . Adapun penjelasnya adalah sebagai berikut:

\section{a. Faktor dari dalam}

Faktor penentu minat belajar dari dalam siswa merupakan fktor yang sangat penting dalam penetuan keberhasilan belajar siswa, faktor itu meliputi motivasi, keingian tahuan, dan yang laiannya. Keinginan tahuan siswa dapat menjadi tolak ukur faktor dari dalam. Siswa yang selalu bertanya dan ingin mencari jawaban dari guru,maka siswa itu dapat mengkombinasikan keingintahuan tersebut dengan belajar, sehingga apa yang menjadi pertanyaan,dapat dipenuhi dengan belajar dan bertanya. Faktor dari dalam siswa sangat berarti ,jika siswa mengahargai diri sendiri dalam hal beraktualifikasi. Siswa mempunyai semangat yang kuat dan tekun yang timbul dari dalam siswa untuk maju. Faktor dari dalam terbentuk dari kesadaran diri dan keinginan kuat dari siswa, tanpa adanya paksaan dan tekanan. Mengetahui lebih banyak tentang sesuatu. Suatu perasaan yang muncul dalam diri seseorang yang mendorong orang tersebut ingin mengetahui sesuatu, 2) motivasi adalah perubahan energi dalam diri seseorang yang ditandai dengan timbulnya perasaan dan reaksi untuk mencapai tujuan. Motivasi adalah sesuatu yang kompleks. Motivasi akan menyebabkan terjadinya suatu perubahan energi yang ada pada diri manusia, sehingga akan bergayut dengan persoalan gejala kejiwaan, perasaan dan juga emosi, untuk kemudian bertindak atau melakukan sesuatu. 3) kebutuhan (motif) yaitu keadaan dalam diri pribadi seorang siswa yang mendorongnya untuk melakukan aktivitas-aktivitas tertentu guna mencapai suatu tujuan. Kebutuhan ini hanya dapat dirasakan sendiri oleh seorang individu. Seseorang tersebut melakukan aktivitas belajar karena ada yang mendorongnya. Dalam hal ini motivasi sebagai dasar penggeraknya yang mendorong seseorang untuk belajar. Dan minat merupakan potensi psikologis yang dapat dimanfaatkan untuk menggali motivasi bila seseorang sudah termotivasi untuk belajar, maka akan melakukan aktivitas belajar dalam rentangan waktu tertentu.

\section{b. Faktor Eksternal}

Faktor eksternal adalah sesuatu yang membuat siswa berminat yang datangnya dari luar diri, seperti: dorongan dari orang tua, dorongan dari guru, tersedianya prasarana dan sarana atau fasilitas, dan keadaan lingkungan. 


\subsection{Metode Partisipatori}

Salah satu metode kooperatif dalam metode partisipatori. Metode ini menekankan pembelajaran siswa aktif. Keterlibatan siswa dituntut penuh ,agar pembelajaran berjalan dengan aktif dan penuh dengan kerjasama. Metode ini dapat menggali kemampuan siswa dengan baik dan terukur. Adapan ciri metode ini adalah ; 1) siswa dan guru timbul komunikasi yang intensif, 2) tidak saling menggurui, siswa dapat bertanya dengan terbuka dan terarah,tdah ada yang superior satu dengan yang lain, 3) pembelajaran diambil dari realita yang ada.

Adapun yang mendasari prinsip pembelajaran partisipatori, bahwa siswa merupakan jiwa yang unik, tidak dapat disamakan satu dengan yang lainnya. Pada pembelajaran ini, siswa mempunyai kekuatan dan kekurangan. Guru tidak dapat menyamakan keunikan siswa, beserta keanekaragam latar belakang dan minat siswa. Guru berangapan bahwa siswa sudah dapat berkembang sendiri dengan segala kelebihan dan keterbatasannya. Untuk itu guru tidak dapat menyamartakan siswa yang ada didalam kelas. Siswa sudah dewasa untuk dapat menentukan keputusannya sendiri,dan guru membantu untuk dapat berkembang semaksimal mungkin. Selain itu dunia siswa adalah dunia bermaian. Guru dapat menemani siswa untuk bermain dan terus berkembang. Guru dapat mencari peluang dan tempat, agar siswa dapat tumbuh menjadi dewasa dan bertangggng jawab. Berikut ini alasan penggunaan metode partisipatori:

1. Pada metode partisipatori, siswa dilibatkan penuh dalam pembelajaran.

2. Yang menjadi subjek pembelajaran adalah siswa.
3. Proses belajar menjadi proses yang menyenangkan.

4. Proses interaksi menjadi pedoman keberhasilan pembelajaran.

Sebagai fasilitator, guru dalam menggunakan metode ini diarapkan memiliki watak sebagai berikut : 1) kepribadian yang menyenangkan dengan kemampuannya dalam membimbing siswa, 2) kemampuan sosial dengan kecakapan menciptakan dinamika kelompok secara bersama-sama dan mengontrolnya tanpa merugikan partisipan / siswa, 3) mampu mendesain cara memfasilitasi yang dapat membangkitkan partisipasi selama proses berlangsung 4) kemampuan mengorganisasi proses dari awal hingga akhir, 5) cermat dalam melihat persoalan pribadi siswa dan berusaha memberikan jalan agar siswa menemukan jalannya, 6) memiliki ketertarikan terhadap subjek belajar, dalam hal ini adalah siswa, 7) fleksibel dalam merespon perubahan kebutuhan belajar siswa, 8) pemahaman yang cukup atas materi pokok pembelajaran. Guru yang dapat mempersiapkan materi dengan baik, maka materi akan tertata dan dapat diberikan kepada siswa dengan baik pula .

Selanjutnya, pembelajaran partisipatori merupakan strategi pembelajaran yang menekankan pada pelibatan siswa untuk berpartisipasi dan ikut menentukan berbagai aktivitas pembelajaran. Aktivitas pembelajaran dapat melibatkan siswa dari kelas lain. Guru dapat mempersiapkan beberapa hal,seperti bahan diskusi, laporan dan evaluasi yang akan digunakan pada akhir pertemuan di kelas. Setiap siswa adalah subjek yang kepentingannya perlu diperhatikan dan diakomodasi dalam proses pembelajaran. Setiap siswa dipandang sebagai indidividu 
yang unik dan berbeda dari satu dengan yang lain. Perlakuan dapat berbeda-beda. Selama proses pembelajaran guru bersifat adil dan dapat melayani semua siswa dengan baik. Pelibatan siswa dalam perencanaan dan penentuan berbagai pilihan tindakan pembelajaran dapat meningkatkan motivasi dan komitmen siswa untuk menekuni setiap tugas pembelajaran. Di samping itu, penggunaan strategi ini dapat mendorong berkembangnya jiwa demokratis serta kemampuan mengemukakan dan menerima pendapat orang lain. Pelaksanaan pembelajaran partisipatori dapat ditempuh melalui strategi sebagai berikut:

a. Libatkan siswa dalam membuat perencanaan dan pilihan tindakan yang diperlukan dalam proses pembelajaran. Misalnya, dalam memutuskan mengenai strategi dan alat-alat pembelajaran, cara-cara menyelesaikan tugas, bentuk dan tugas kelompok, ataupun ketentuanketentuan lain yang diperlukan.

b. Gunakan berbagai teknik, seperti brainstorming, meta-plan, diskusi kelompok fokus untuk mendorong semua siswa mengemukakan ide dan pendapat masing-masing. Pendapat tersebut dapat dijadikan acuan dalam menentukan hasil pembelajaran berikutnya.

c. Evaluasi setiap alternatif berdasarkan kelayakan (kemampuan, sumber daya, waktu, fasilitas), kemudian sepakati pilihan yang dapat diterima semua pihak. Dimungkinkan setiap individu atau kelompok memilih caranya masing-masing untuk mencapai tujuan sepanjang berkontribusi pada pencapaian tujuan pembelajaran. Evaluasi dapat dilaksanakan didalam atau di luar kelas, sepanjang mempunyai parameter yang jelas dan sesuai dengan tujuan pembelajaran.

d. Dorong siswa melaksanakan alternatif tindakan secara konsisten, namun tetap memberi peluang dilakukannya refleksi, revisi, dan perubahan rencana tindakan. Perubahan tindakan dapat dilaksanakan sepanjang tidak mengubah tujuan pembelajaran.

\subsection{Pengertian Kewirausahaan}

Kewirausahaan berasal dari kata wira dan usaha. Wira, berarti pejuang, pahlawan, manusia unggul, teladan, berbudi luhur, gagah berani dan berwatak agung. Usaha, berarti perbuatan amal, bekerja, berbuat sesuatu. Jadi, definisi wirausaha berdasarkan etimologi adalah pejuang atau pahlawan yang berbuat sesuatu, ini baru dari segi etimologi. (Menurut Dr Basrowi. 2014, hal: 1 dalam bukunya: Kewirausahaan untuk Perguruan Tinggi). Seseorang dikatakan punya jiwa wirausaha bila jeli melihat peluang, pantang menyerah, kreatif dan inovatif, dan berani mengambil resiko. Karakteristik seperti itulah yang mendorong maju tidaknya sebuah usaha (Menurut Dr. H. Moh. Alifudin, MM dan Dr. H. Mashur Razak, MM. 2015:29, dalam buku Kewirausahaan: Strategi Membangun Kerajaan Bisnis). Menurut Prof.Dr.H.Buchari Alma. 2014:33 dalam bukunya Kewirausahaan untuk Siswa dan Umum, Kewirausahaan adalah proses dinamik untuk menciptakan tambahan kemakmuran. Tambahan kemakmuran ini diciptakan oleh individu wirausaha yang menanggung resiko, menghabiskan waktu dan menyediakan berbagai produk barang dan jasa. Barang dan jasa yang dihasilkannya boleh saja bukan merupakan produk baru tetapi mesti mempunyai nilai yang baru dan berguna dengan 
memanfaatkan skills dan resources yang ada. Wirausaha merupakan suatu kegiatan yang bertumpu dari kemampuan siri sendiri,sehingga dapat diembangkan dari diri sendiri menjadi kemampuan membuka lapangan pekerjaan baru dan mengembangkan lebih luas lagi.

Manfaat yang paling dapat dirasakan adalah dapat memberikan pekerjaan bagi banyak orang. Jumlah pengangguran dapat dikurangi,sehingga pertumbuhan ekonomi dapt tumpuh positif.

Ciri ciri kewirausahawan yang para siswa dan profesional 1) mempunyai keyakinan akan produk sendiri. 2)produk yang dibuat sangat dikenal. 3) menghindari perebatan dengan pelanggan. 4) dapat berkomunikasi dan ramah pada pelanggan. 5) jujur dan berani. 6) dapat menciptakan transaksi yang banyak . Etka dan kejujuran dangat dijunjung tinggi. Hal tersebut merupakan al yang tidak bisa dtawar lagi. Kebiasaan berbisnis yang jujur, santun dan etis merupakan keharusan dalam suatu perusahaan.

\subsection{Tujuan Berwirausaha}

Berikut beberapa tujuan dari seorang wirausaha yang seharusnya: 1) berusaha dan bertekad dalam meningkatkan jumlah para wirausaha yang baik dengan kata lain ikut serta dalam mengkader manusia manusia calon wirausaha untuk membangun jaringan bisnis yang lebih baik. 2) ikut serta dalam mewujudkan kemampuan para wirausaha untuk meningkatkan kesejahteraan dan kemakmuran masyarakat dan negaranya. 3) ikut serta dalam menumbuhkan dan mengembangkan kesadaran serta orientasi kewirausahaan yang kokoh. 4) menyebar luaskan dan membuat budaya ciri ciri kewirausahaan disesiswarnya terutama dalam masyarakat. 5) mengembangkan dalam bentuk inovasi dan kreasi agar tercipta dinamika dalam kewirausahaan atau dunia bisnis sehingga kemakmuran dapat tercapai. Target pertumbuhan yang dicanangkan oleh pemerintah dapat tercapai.

\section{METODE}

Subjek penelitian ini adalah siswa SMK Dreiwanti. Populasi terjangkau dalam penelitian jumlah seluruhan siswa SMK Dreiwanti tahun ajaran 2017-2018. Peneliti mengambil sampel dengan teknik sampling random,sebanyak 25 siswa kelas $X$ dan XI SMK Drewanti. Data pembelajaran partisipatori dan minat belajar diambil dara angket yang telah diisi oleh siswa.. Data akan diolah secara kuantitatif dengan menggunakan model statistik parametik, dalam program komputer SPSS 22 seperti analisis deskriptif dan regresi berganda siswa. Namun sebelum analisis itu dilalui akan dilakukan uji homogenitas dan linearitas. Apabila telah memenuhi syarat uji tersebut, maka berikutnya dilakukan perhitungkan analisis SPSS 22, selanjutnya diadakan interprestasi terhadap hasil analisis tersebut. Teknik pengambilan data memakai kuesioner untuk minat belajar dan pembelajaran partisipatori, sedangkan hasil belajar dengan memakai tes. Siswa SMK dreiwanti yang menjadi sampel penelitian terdiri dari 10 siswa pria dan 15 siswa wanita.

\section{HASIL DAN PEMBAHASAN}

\subsection{Potensi Pembelajaran Pada}

\section{Kewirausahaan}

$\begin{array}{rccr}\text { David } & \text { dalam Sanjaya } & (2009: 42) \\ \text { menyebutkan } & \text { bahwa dalam } & \text { strategi } \\ \text { pembelajaran } & \text { terkandung } & \text { makna }\end{array}$


perencanaan, artinya: strategi pada dasarnya masih bersifat konseptual tentang keputusan-keputusan yang akan diambil dalam suatu pelaksanaan pembelajaran. Perbedaan daya serap siswa mata kuliah kewirausahaan, memerlukan strategi yang tepat. Dalam satu kelas kemampuan siswa untuk menyerap pelajaran berbeda-beda, demikian gaya belajarnya. Sebagian siswa mungkin condong pada kemampuan menangkap pelajaran berdasarkan audiotori, visual, maupun audiovisual. Pemilihan metode pembelajaran yang tepat akan mampu mengatasi perbedaan daya serap tersebut. Sebisa mungkin siswa diajak untuk mempraktekan langsung dilapangan, dengan cara membuat business plan, menyajikan sejumlah materi kewirausahaan dan contohnya via media visual di dalam kelas sehingga siswa mudah menyerap pelajaran dengan baik.Strategi pembelajaran dapat ditinjau berdasarkan pengertian secara sempit dan pengertian secara luas. Secara sempit strategi pembelajaran dapat diartikan sebagai cara yang digunakan untuk mencapai Pemakaian metode partisipatori merupakan pilihan metode yang dapat digunakan dalam pembelajaran kewirausahaan. Siswa mampu mengembangkan wawasan mereka dalam berkomunikasi dengan siswa lain. Siswa termotivasi dan dapat menggunakan keahlianya dalam beradaptasi dengan lingkungan dan kurikulum serta materi.

Kewirausahaan memerlukan komunikasi yang baik. Kemampuan komunikasi dengan orang lain ,dapat diuji dengan metode partisipatori,karena metode ini menekankan interaksi yang intensif. Pembelajaran partisipatori mengajarkan siswa untuk berani berkomunikasi dan santun berbicara. Kesuksesan berwirausaha ada kaitanya dengan kemampuan berinteraksi dengan pihak lain. Produk yang baik dan berkualitas tidak dapat dikenal ,jika dalam penyampaian berkomunikasi kurang. Pelanggan kuran memahami ,manfaat dan keunggulan produk yang ditawarkan. Siswa dapat melakukan penawaran produk ,jika siswa dapat memahami produk itu. Simulasi dan pelatihan penawaran dengan berkomunikasi perlu diadakan . Penyampaian penawaran produk ,harusla dikomunikasikan dengan baik, agar konsumen tidak ragu untuk membeli produk unggulan. Konsumen yang yakin dengan produk yang dibeli,maka menjadi keuntungan yang dapat menjadi bekal siswa untuk menjadi pengusaha sukses.

Siswa diharapkan mempunyai visi yang tepat dalam menentukan masa depanya kelak. Siswa dapat mempunyai cita-cita yang baik,sehingga visinya dapat terwujud. Visi yang terbentuk lebih awal,akan membantu siswa mewujudkan dengan baik. Siswa dapat bekerja keras dalam meraih cita-citanya. Kerja keras merupakan keharusan, agar usaha yang dijalankan dapat mewujudkan cita-citanya,khususnya dalam mewujudkan usaha mandiri. Namun untuk mewujudkan usaha itu,perlu adanya pengorbanan. Siswa akan menemui hambatan dan tantangan yang tidak mudah. Pendampingan guru pada siswa perlu dilakukan,agar siswa dapat menyelesaiakan segala hambatan dan tantangan yang akan ditemui kelak. Pemahaman akan keberadaan tuhan juga perlu difahami bagi siswa. Tanpa doa dan dukungan dari tuhan pencipta alam,semuanya tidak akan terjadi. Kemajuan teknologi akan mempengaruhibisnis yang akan dijalanakan. Industri 4.0 ,akan menjadikan kehidupan bergerak maju,dalam artian,siswa menyesuaikan diri . Manusia akan menemukan hal yang baru untuk mempermudah kehidupannya. Seiring dengan kemajuan zaman. Hal - hal yang baru akan menciptakan masalah baru. Akibatnya diperlukan profesi,pekerjaan dan bisnis yang bau untuk memberikan solusi 
terhadap masalah-masalah baru yang timbul akibat kemajuan zaman. Penyesuaianpenyesuaian itu akan berdampak buruk, jika siswa tidak dapat mengikuti perkembangan zman yang demikian cepat. Sehingga dengan persiapan yang baik dan sedini mungkin, siswa akan dapat mempersiapkan dirinya dengan perubahan yang akan berubah lebih menjamin kesuksesan dan pasti sulit dibajak pesaing manapun.

Dalam rangka menumbuhkan minat berwirausaha, siswa juga dianjurkan untuk membiasakan berolahraga, demi menjaga kebugaran tubuh. Hal ini perlu dilakukan , karena pada fasu awal memulai wirausaha,diperlukan energi yang cukup tinggi. Kebutuhan nutrisi yang cukup dan istirahat yang tepat,merupakan keharusan yang dimiliki oleh seorang wirausaha. Dengan bekal fisik dan mental yang baik, seorang wirausaha dapat menmperbaharui visi dan misi mereka setiap saat,mengikuti perkembangan zaman. Visi dan misi yang dituangkan kedalam rencana, akan mempermudah siswa untuk dapat menjapai rencana jangka pendek, menengah dan panjang. Pada pencapaian jangka pendek,siswa dapat memperbaiki kekurangan dan kelemahan yang timbul dalam pencapaian jangka pendek. Siswa dilatih untuk terus memperbaharui dan memperbaiki visi dan misi mereka. Kekuatan dan ketahanan (endurance) dari tiap siswa berbeda. Kebanyakan siswa akan mudah menyerah, jika ada hambatan yang menghadang mereka. Siswa yang mempunyai ketahanan yang kuat, akan terus berjuang memperbaiki hasil yang dicapai. Jika hasil yang dicapai kurang memuaskan, maka tidak segan-segan siswa bertanya kepada mentor dan kepada orang berpengalaman. Siswa yang mengerjakan suatu tahapan usaha bisnis dengan konsistenmaka ia akan memperoleh ilmu dan pengalaman yang dapat menjadi dasar perbaikan dan revisi dikemudian hari. Dari pengalaman yag dialami sendiri siswa dapat belajar, learning by doing. Konsistn sanat diperlukan,dengan pengorganisasian tim dan ekspansi usaha,maka seorang wirausahawan dipacu untuk dapat mengembangkan usaha,agar dapat berkembang sesuai dengan rencana jangka menengah dan panjang. Pengembangan usaha meliputi target pasar dan produk yang akan dibuat.

Siswa yang dapat memenuhi keinginan pasar dan selalu membuka diri dari kritik dan masukan, maka dia dapat membangun hubugan yang baik dengan konsumen. Dengan menghargai dan bersikap sopan terhadap konsumen maka konsumen akan bersikap setia pada produkdan jasa yang mereka sudah beli. Kreatifitas para siswa dapat dilakukan dengan cara mengubah produk yang biasa menjadi luar biasa.Produk yang berdaya guna tinggi. Pelanggan yang jeli, akan selalu mencoba produk-produk yang lain dari pada yang lain. Seperti baru-baru ini produsen bakso, yang membuat baksonya dengan isi duren di Medan. Hal ini merupakan terobosan baru yang perlu disikapi dengan baik. Kreativitas bermula dari pola pikir siswa. Pola pikir yang dibarengi dengan soft skill yang baik, maka siswa dapat mengembangkan keterampilan dan produknya ke pasar yang lebih luas. Dari lokal menjadi internasional. Dengan memiliki karakter yang baik, siswa dapat dengan mudah berpeluang menjadi wirausahawan. Bagaimana mungkin seorang wirausahawan yang tidak mempunyai karakter, dapat mengemangkan usahanya dengan baik. Peanggan akan mencibirkan dan meninggalkannya. Proses menjadi wirausahawan, dapat dimulai di sekolah. Dengan pengetahuan melalui proses belajar pada masa sekolah atau kuliah, dengan pelajaran-pelajaran yang dipelajari merupakan salah satu sumber pengetahuan 
yang dapat dijalankan pada masa depan. Semua penjelasan di atas menandakan bahwa menjadi wirausahawan diperlukan modal dan tekad yang kuat, serta networking yang luas. Dengan networking yang luas, maka produk dapat dikenal dengan baik dan luas. Hubungan yang baik dan erat apat membantu dan mempermudah market dari suatu produk dan jasa yang akan dipasarkan. Agar dapat mempuyai networking yang luas, siswa dibiasakan untuk bergaul dengan siswa lain tanpa membedak-bedaka suku, agama, ras dan golongan, Semuanya sama dan penting demi membangun networking yang kuat. Selanjutnya matematika mempunyai hubungan yang erat dengan kewirausahawan yaitu :

1) Aritmatika masyarakat, untung dan rugi. dalam suatu usaha yang siswa jalankan pasti terdapat untung dan rugi. Sedangkan untung dan rugi merupakan salah satu dari materi matematika yang siswa pelajari.Sehingga dalam kewirausahaan juga harus mempelajari bagaimana cara menghitungrugi maupun laba yang diperoleh dalam usaha yang siswa jalankan

2) Geometri merupakan salah satu dari cabang matematika. Berbagai macam bentuk bangun geometri seperti balok, kubus, bangun datar, dll, dapat siswa gunakan dalam bidang wirausaha. Sebagai contoh misalnya: siswa membuat suatu produk diperlukankemasan semenarik mungkin supaya lebih efektif dan efisien. Selain itu bentuk suatu produk juga mempengaruhi keindahan barang. Dengan bentuk yang unik dan menarik akan membuat orang tertarik untuk membelinya.

3) Statistika untuk menghitung rata-rata diperlukan ilmu statistika. Dalam bidang wirausaha juga diperlukan ilmu berhitung ini. Sebagai contoh misalnya, rata-rata penghasilan yang diperoleh per-hari, minggu, bulan, dan lain-lain. Rata-rata barang yang dihasilkan dalam suatu usaha.
Statistika juga mempelajari bagaimana cara menyajikan data yang diperoleh dalam bentuk diagram juga tidak terlepas dalam bidang usaha untuk membuatlaporan keuangan. Dari uraian di atas dapat disimpulkan bahwa peran pembelajaran sangat penting dalam berbagai bidang, salah satu nya adalah kewirausahaan.

\subsection{Menanamkan Kewirausahaan SMK}

Pendapat agar kewirausahaan dimasukkan kedalam pelajaran sekolah merupakan hal yang tidak bisa ditawar lagi. Indonesia merupakan negara berpenduduk terbesar di Asia tenggara, Indonesia dapat menjadi pangsa pasar yang empuk bagi negara lain, jika bangsa Indonesia sendiri yang tidak menggarap produk-produk buatan Indonesia. Serbuan negara aisng akan masuk dengan cepat,jika tidak diantisipasi sejak awal. Kewirausahaan dapat menjadikan siswa mandiri, bahkan dapat membuka peluang kerja yang lebih luas bagi masyarakat yang kurang mampu. SMK sudah mewajibkan pelajaran kewirausahaan menjadi pelajaran yang harus diikuti. Penyesuaian kurikulum sekolah dengan kebutuhan industry dapat dilakukan sesuai dengankebutuhan yang diperluakan dalam industry kerja. Memperbaharui kurikulum dan materi disekolah sangat penting dan wajib, agar siswa dapat bersaing dengan negara lain. Sebagai contoh disekolahsekolah sudah mengadakan "market day". Sekolah memfasilitasi kegiatan tersebut, dengan menampilkan produk dan jasa hasil dari tangan-tangan terampil siswa. Siswa dapat mempromosikan produk mereka kepada masyarakat dan para orang tua. Pada perencanaan kegiatan "market day" siswa merencanakan kebgitan dengan membuat daftar barang penjualan dan pembuatan produk tertentu, dimula dari produk olahan makanan, minuman dan jasa. Pada saat mempromosikan produk-produknya, siswa 
dapat membuat brosur,pamlet,iklan indoor dan iklan yang berbentuk digital.

Kebutuhan akan pemenuhan kebutuhan manusia yang teu meningkat, merupakan tantangan tersendiri bagi para wirusahawan untuk dapat berlomba-lomba memenuhi kebutuhan tersebut. Jika berbicara wirausaha, tentuya tidak dapat lepas dari pembelajaran di sekolah. Sebagai contoh, siswa yang belajar berwirusaha, tidak lepas dari kemampuan berhitung rugi dan laba. Siswa harus memahami rugi dan laba. Sehingga antara pembelajaran dan wirausaha tidak dapat dipisahkan satu dengan yang lain. Pada saat siswa mengelola barang dagangannya,dengan menggunakan keterampiln berbahasanya, siswa dapat berkomunikasi denan lemah lembut .Stok dagangan yang disimpan kedalam data komputer,merupakan keterampilan yang sangat berguna dalam pengelolaan berwirausahaan.

Selanjutnya para pakar berpendapat bahwa kewirausahaan dalam kaitannya dengan ciri-ciri isla adalah sebagai berikut :
a) Sidik
b) Amanah
c) Fatonah
d) Membantu yang lemah
e) Tawakal

Selanjutnya dapat dikatakan bahwa kewirausahaan merupakan serangkaian sikap hidup yang dibutuhkan untuk aktivitas wira-usaha. Sikap hidup tersebut diantaranya adalah, jujur, kreatif, inovatif, percaya diri, tahan banting dan berani mengambil resiko. Jika demikian maka pada dasarnya dapat dikatakan bahwa kewirausahaan juga merupakan suatu karakter yang dapat dibangun melaluiserangkaian proses pembelajaran. Senada dengan pendapat ini, sejumlah karakter kewirausahaan yang paling menonjol adalah memiliki kegigihan, siap menghadapi tantangan, jeli melihat keadaan dan peluang, kreatif, berpikir lebih terbuka dan tidak terkotak-kotakkan, atau berpikir out of the box. Siswa yang dapat berpikir dengan keberanian dan tidak mudah menyerah akan mendapat kesuksesan dalam berwirusaha. Siswa yang terbiasa diberikan suatu proyek bisnis disekolah,diharapkan ketika selesai sekolah, mereka sudah mempunyai bekal untuk berwirusaha .

\subsection{Uji Data Normalitas Dan Linearitas}

Data yang sudah diambil melalui angket dan tes, diolah dengan menggunakan alat bantu SPSS 21. Pengambilan data dilakukan di sekolah SMK Drewanti pada tanggal 12 November 2018. Peneliti memberikan arahan dan penjelasan kepada siswa. Para siswa mengerjakan tes kemampuan kewirausahan, dengan 2 jenis tes, yang pertama, tes praktek melakukan serangkaian perencanaan, mengolah sampai dengan memasarkan produk seperti makanan olahan, produk dijual secara daring, dan penjualan beberapa produk minuman. Dari hasil yang diperolah setelah diolah data pembelajaran partisipatori (X1), minat belajar (X2), dan minat kewirausahaan ( Y), maka didapat hasil sebagai berikut :

Tabel. 1. Tabel uji Kolmogorof-Smirnov test

\begin{tabular}{|c|c|c|c|c|}
\hline \multicolumn{5}{|c|}{ One-Sample Kolmogorov-Smirnov Test } \\
\hline & & $\mathrm{X} 1$ & $\mathrm{X} 2$ & $\mathrm{Y}$ \\
\hline \multicolumn{2}{|l|}{$\mathrm{N}$} & 25 & 25 & 25 \\
\hline \multirow{2}{*}{$\begin{array}{l}\text { Normal } \\
\text { Parameters }\end{array}$} & Mean & 47.2800 & 54.0800 & 3.2960 \\
\hline & $\begin{array}{l}\text { Std. } \\
\text { Deviation }\end{array}$ & 15.20833 & 5.36128 & .16902 \\
\hline \multirow{3}{*}{$\begin{array}{l}\text { Most } \\
\text { Extreme } \\
\text { Differences }\end{array}$} & Absolute & .160 & .102 & .109 \\
\hline & Positive & .160 & .072 & .101 \\
\hline & Negative & -.071 & -.102 & -.109 \\
\hline \multicolumn{2}{|l|}{ Test Statistic } & .160 & .102 & .109 \\
\hline \multicolumn{2}{|c|}{ Asymp. Sig. (2-tailed) } & $.100^{c}$ & $.200^{\mathrm{c}, \mathrm{d}}$ & $.200^{\mathrm{c}, \mathrm{d}}$ \\
\hline
\end{tabular}


b. Calculated from data.

c. Lilliefors Significance Correction.

d. This is a lower bound of the true significance.

Pada Tabel 1, nilai Sig.. pada varibel X1, X2 dan Y, masing-masing sebesar, $0.1,0.2$ dan 0.2 yang artinya nilai $\mathrm{Sig}$. $>0.05$, berarti data tersebut berdistribusi normal. Oleh karena data sudah berdistribusi normal, maka peneliti meneruskan pengolahan data, ke uji Linearitas X1 ke Y. Pada pengolahan data linearitas dapat dilihat pada tabel. 2 di bawah ini.

Tabel 2. Tabel linearitas 1

ANOVA Table

\begin{tabular}{|c|c|c|c|c|c|c|c|c|}
\hline \multirow{3}{*}{$\begin{array}{l}\mathrm{Y} \\
* \\
\mathrm{X} 1\end{array}$} & \multirow{4}{*}{$\begin{array}{l}\text { Between } \\
\text { Groups }\end{array}$} & \multirow{2}{*}{$\begin{array}{r}\begin{array}{c}\text { Sum of } \\
\text { Squares }\end{array} \\
\text { (Combined) }\end{array}$} & \multicolumn{2}{|r|}{$d f$} & \multicolumn{2}{|c|}{$\begin{array}{c}\text { Mean } \\
\text { Square }\end{array}$} & $F$ & ig. \\
\hline & & & .571 & & 14 & .041 & 3.550 & .025 \\
\hline & & Linearity & .046 & & 1 & .046 & 4.015 & .073 \\
\hline & & $\begin{array}{l}\text { Deviation } \\
\text { from } \\
\text { Linearity }\end{array}$ & .525 & & 13 & .040 & 3.514 & .027 \\
\hline & $\begin{array}{l}\text { Within } \\
\text { Groups }\end{array}$ & & & 10 & & & & \\
\hline & Total & & & 24 & & & & \\
\hline
\end{tabular}

Tabel 3. Tabel linearitas 2

\begin{tabular}{|c|c|c|c|c|c|c|c|}
\hline \multicolumn{8}{|c|}{ ANOVA Table } \\
\hline & & & $\begin{array}{c}\text { Sum of } \\
\text { Square } \\
\text { s }\end{array}$ & df & $\begin{array}{c}\text { Mean } \\
\text { Squa } \\
\text { re }\end{array}$ & $\mathrm{F}$ & $\begin{array}{c}\text { Sig } \\
.\end{array}$ \\
\hline \multirow{8}{*}{$\begin{array}{l}Y \\
* \\
X \\
1\end{array}$} & Betwe & (Combin & 1506.1 & & & 2.27 & .15 \\
\hline & en & ed) & 40 & 18 & .041 & 7 & 7 \\
\hline & Group & Linearity & & 1 & & 2.16 & .19 \\
\hline & $\mathrm{s}$ & & 79.425 & 1 & .046 & 1 & 2 \\
\hline & & $\begin{array}{l}\text { Deviation } \\
\text { from }\end{array}$ & 1426.7 & 17 & .040 & 2.28 & .01 \\
\hline & & Linearity & & & & & 6 \\
\hline & Within & oups & $\begin{array}{r}220.50 \\
0\end{array}$ & 6 & .011 & & \\
\hline & Total & & $\begin{array}{r}1726.5 \\
40\end{array}$ & 24 & & & \\
\hline
\end{tabular}

Berdasarkan hasil analisis di atas menunjukkan bahwa nila $\mathrm{F}$ yang ditemukan adalah sebesar 3,514 dengan sig 0,027.. Oleh karena nilai sig tersebut $<0,05$ maka dapat disimpulkan bahwa hubungan antara variabel uang saku dan prestasi belajar bersifat tidak linear.
Tabel 4. Tabel enter variabel

\begin{tabular}{clcc}
\hline Model & $\begin{array}{l}\text { Variables } \\
\text { Entered }\end{array}$ & $\begin{array}{c}\text { Variables } \\
\text { Removed }\end{array}$ & Method \\
\hline 1 & $\mathrm{x} 2 . \mathrm{x} 1$ & & Enter \\
\hline
\end{tabular}

Pada tabel diatas, peneliti telah memasukkan semua data, dan terlihat pada data entered variabel. Adapun data yang telah masuk adalah data minat belajar, pembelajaran dan kemampuan berwirausaha.

Tabel. 5. Tabel model summary

\begin{tabular}{ccccc}
\multicolumn{6}{c}{ Model Summary } \\
\hline Model & R & R Squared & Adjusted R & $\begin{array}{c}\text { Std. Error of } \\
\text { the Estimate }\end{array}$ \\
\hline 1 & .554 & .306 & .243 & 7.378 \\
\hline
\end{tabular}

Hasil di atas menunjukkan koefisien korelasi ganda $\mathrm{R}$ sebesar 0,306. Koefisien tersebut signifikan karena setelah diuji ,dengan kata lain pembelajaran dan minat baca berkontribusi sebanyak 30.6\%, sedangkan sisanya dipengaruhi faktor lain. Faktor pembelajaran partisipatori dapat dikatakan mempengaruhi kemampuan berwirausaha, walaupun kecil, namun siswa dapat ditingkatkan kemampuan berwirausaha dengan menggunakan metode lain, seperti pembelajaran berbasis proyek dan yang lainnya.

Tabel 6. Tabel anova

\begin{tabular}{ccccccc}
\hline & & Sum of & & Mean & & \\
& & Squares & df & Square & $\mathrm{F}$ & Sig. \\
\hline 1 & Reggressio & 529.051 & 2 & 264.52 & 4.85 & .01 \\
$\mathrm{n}$ & 1197.58 & 22 & & 9 & 8 \\
& Residual & 9 & 22 & & & \\
& & 1726.64 & 24 & & & \\
\hline & & 0 & 24 & & &
\end{tabular}


Pada tabel 4 (Anova) menunjukkan bahwa nilai Sig. sebesar $0.018<0.05$, hal tersebut dapat dikatakan bahwa pengaruh pembelajaran dan minat belajar berpengaruh kepada kemampuan berwirausaha. Variabel $\mathrm{X} 1$ dan X2 secara bersama-sama mempunyai pengaruh terhadap kemampuan berwirausaha. Variabel X1 sebagai pembelajaran menandakan masih dapat berkontribusi pada kemampuan berwirausaha siswa SMK.

\section{Tabel 7. Tabel koofesien}

\begin{tabular}{|c|c|c|c|c|c|c|}
\hline \multirow[b]{3}{*}{ Model } & & Coofficients & & & & \\
\hline & \multicolumn{2}{|c|}{ Unstandardized Coefficients } & \multicolumn{2}{|c|}{ Standard Coeefficient } & $\mathrm{t}$ & Sig. \\
\hline & & B & Std.Error & Beta & & \\
\hline \multirow[t]{3}{*}{1} & Constant & 43.647 & 8.947 & & 4.88 & 0,000 \\
\hline & $\mathrm{X} 1$ & 0.554 & 0.193 & 0.734 & 2.87 & 0.009 \\
\hline & $\mathrm{X} 2$ & 0.131 & 0.103 & 0.312 & -1.22 & 0.234 \\
\hline
\end{tabular}

Bagian ini menampilkan hasil ,pengujian koefisien determinasi. Hasil pengujian tersebut ditemukan nilai, Sig. pembelajaran sebesar $0.009<0,05$. Oleh karena nilai sig. $<0,05$ maka Ho $(\rho=0)$ ditolak yang artinya pembelajaran partisipatori memiliki pengaruh yang signifikan terhadap kemampuan wirausaha. Sedangkan pada minat belajar nilai Sig. $0.234>0.05$, yang berarti minat belajar tidak berpengaruh pada kemampuan wirausaha. X2 ( Minat belajar) tidak berpengaruh terhadap kemapuan berwirausaha, hal ini dimungkinkan karena minat belajar mempunyai andil yang kecil pada penelitian di SMK Dreiwanti.

Pada hasil diatas menandakan bahwa metode partisipatori dapat membantu siswa untuk meningkatkan kemampuan wirausaha mereka. Kemampuan wirausaha perlu diasah, agar siswa terbiasa dalam menghadapi gejolak yang akan terjadi sewaktu-waktu. Para siswa dapat mengembangkan kemampuan wirausaha . Metode partisipatori yang dipadukan dengan pembelajaran di luar kelas dapat digunakan sebagai salah satu alternatif pembelajaran yang menyenangkan (Purwanto, 2018). Metode ini dapat memberikan efek positif, dalam pembelajaran. Siswa lebih aktif dan tidak mudah bosan. Pembelajaran yang genuine (asli) akan mempunyai efek yang lebih lama, dan melekat pada diri siswa lebih lama.ketimbang pembelajaran yang artifisial ( buatan ). Oleh karena itu, tidak saja dalam pembelajaran untuk meningkatkan minat wirausaha,namun pada bidang-bidang lain perlu juga di terapkan di kelas,agar mendapat hasil yang optimal dan sesuai dengan tujuan pembelajaran . Guru dapat memvariasikan metode pembelajaran dengan metode lain (Widiyarto, 2017). Oleh karena faktor pembelajaran berpengaruh kepada kemampuan berwirausaha dapat dirangkum beberapa alasan mengapa, guru disarankan menggunakan metode partisipatori,

\section{Alasan Penggunaan Metode Partisipatori}

1. Metode partisipatori menekankan keterlibatan siswa secara penuh.

2. Siswa ditempatkan sebagai subjek pembelajaran.

3. Kegiatan belajar mengajar diharapkan berlangsung menyenangkan.

4. Terjadi interaksi positif antara pengajar dengan pembelajar.

Sanjaya (2011:13-14) menyatakan Pembelajaran merupakan suatu sistem yang kompleks yang keberhasilannya dapat dilihat dari dua aspek yaitu aspek produk dan aspek proses. Keberhasilan pembelajaran dilihat dari sisi produk adalah keberhasilan siswa mengenai hasil yang diperoleh dengan mengabaikan proses pembelajaran. Proses itu dapat berlangsung didalam tau di luar kelas. 
Keberhasilan pembelajaran dilihat dari sisi hasil memang mudah dilihat dan ditentukan kriteriannya, akan tetapi hal ini dapat mengurangi makna proses pembelajaran sebagai proses yang mengandung nilai-nilai pendidikan yang lebihbaik dan lebih mengenai sasaran.

\section{KESIMPULAN}

Setelah membahas hasil penelitian, tim peneliti menilai bahwa, metode yang sudah diaplikasikan disekolah mempunyai beberapa keunggulan serta kekuranganya. Namun pada penelitian di SMK Dreiwanti siswa terlihat lebih rileks dan tidak merasa bosan ketika menggali, dan mencoba mempelajari beberapa bahasan yang diberikan oleh guru. Pihak sekolah sudah memfasilitasi pada proses pembelajaran ini. Berdasarkan pembahasan di atas ,maka dapat disimpulkan hasil penelitian sebagai berikut:
a. Terdapat pengaruh pembelajaran partisipatori dan minat belajar secara simultan terhadap kemampuan berwirausaha.
b. Terdapat pengaruh pembelajaran partisipatori terhadap kemampuan berwirausaha.
c. Tidak terdapat pengaruh minat belajar terhadap kemampuan berwirausaha.

\section{DAFTAR PUSTAKA}

Ati, A. P., Widiyarto, S., \& Suyana, N. (2018). Penerapan Metode Picture And Picture Untuk Peningkatan Keterampilan Menulis Narasi Pada

Siswa Kelas VIII Smp Al Ihsan Dan Smp Tashfia Kota Bekasi. Adimas:
Jurnal Pengabdian $\quad$ Kepada
Masyarakat, 2(1), 30-36.

Basrowi (2014) Kewirausahaan untuk Perguruan Tinggi, Bandung: AlfaBeta.

Cristian, M. (2018) Anti salah Jurusan „Jakarta: Gramedia Widisyawara

Sanjaya, Wina (2011) Strategi

Pembelajaran, Jakarta: PT. Kencana,

Suprapto, H. A. (2018). Strategi Pembelajaran Kewirausahaan Berbasis Teknologi Informasi (TI) Terhadap Peningkatan Minat Siswa Menjadi Wirausaha. Didaktis: Jurnal Pendidikan dan Ilmu Pengetahuan, 18(1).

Suyana, N., Ati, A. P., \& Widiyarto, S. (2019). Metode Partisipatori untuk Meningkatkan Kemampuan Menulis Argumentasi Pada Siswa MTs Nurul Hikmah Kota Bekasi. Linguista: Jurnal Ilmiah Bahasa, Sastra, dan Pembelajarannya, 2(2), 80-86.

Sanjaya, Wina. 2011. Strategi Pembelajaran: Berorientasi Standar Proses Pendidikan. Jakarta. Kencana Prenada

Sujadna, S. Dkk. 2010. Metode dan Tehnik Pembelajaran Partsipatif. Bandung. Falah Production.

Vernia, D. M. (2018). Faktor-Faktor Yang Mempengaruhi Intensi Berwirausaha Siswa Kelas Xi Smk Mitra Bakti Husada Bekasi. Lectura: Jurnal Pendidikan, 9(2), 105-114.

Vernia, D. M., Suprapto, H. A., \& Supandi, A. (2018). Penyuluhan Pentingnya 
Minat Kewirausahaan Dalam Membentuk Karakter Mandiri Siswa Smk Insan Mulia dan SMP Azzuhriyah Kota Bekasi. MATAPPA: Jurnal Pengabdian Kepada Masyarakat, 1(2), 54-58.

Widiyarto, S. (2017). Pengaruh Minat

Belajar Dan Pemahaman Kalimat Terhadap Kemampuan Menulis
Kalimat Efektif. Mendidik: Jurnal Kajian Pendidikan Dan Pengajaran, 3(2), 169-177.

Widiyarto, S. (2018). Pengaruh Metode Cooperative Scrift dan Peran Orang Tua Terhadap Prestasi Belajar Bahasa Indonesia. KHAZANAH PENDIDIKAN, 11(1). 